\title{
Epidemiological Research for Who has Ischemic Diseases While Using Effective Oral Anticoagulant Drug
}

Etkin Düzeyde Oral Antikoagülan Kullanan Hastalarda Tekrarlayan İskemik Hastalıkların Epidemiyolojik İncelenmesi

\section{Kadir Dibek¹, (D) Seda Özkan², (D) Sinan Yıldırım³, (D) Selim Genç4, (D) Sinem Burul Alp ${ }^{5}$}

1-Bandırma Devlet Hastanesi, Balıkesir, 2- İstanbul Üniversitesi-Cerrahpaşa, Cerrahpaşa Tıp Fakültesi, İstanbul, 3Çanakkale Devlet Hastanesi, Çanakkale, 4-Dışkapı Yıldırım Beyazıt Eğitim ve Araştırma Hastanesi, Ankara, 5-Aydın Devlet Hastanesi, Aydın

\begin{abstract}
Objective: Many complications can occur while treating the ischemic diseases, also under treatment,some patients have recurrent ischemic diseases. In our study we aimed that to investigate dermographic characteristics, risk factors, and causes for patients, who has ischemic disease while under treatment of oral anticoagulant therapy for any reason and international normalised ratio (INR) levels between 2-3.

Materials and Methods: The files of patients diagnosed with myocardial infarction, ischemic cerebro vascular disease and pulmonary embolism who applied to the emergency department between 01.01.2014 and 31.12.2015 were analyzed retrospectively. The data of patients with an INR value of 2-3 and using oral anticoagulants were found from the hospital automation system. The data obtained were evaluated with the SPSS 17 Statistical analysis program.

Results: The INR value was determined in 2-3 of 452 pulmonary embolus patients, 24 of 1442 ischemic cerebrovascular patients, and 55 of 1263 myocardial infarction patients. 6 people from 55 patients with myocardial infarction, 3 people from 24 patients with pulmonary embolism and 3 people from 24 patients with stroke had the same disease before. The patients who diagnosed with pulmonary embolism, were seen less frequently received high Wells scores and big vessels embolism in the group with INR levels in treatment range. The patients diagnosed with stroke whose INR levels in treatment range, had atrial fibrillation more frequently. Congestive heart failure, atrial fibrillation and pulmonary embolism were found to be high risk factors in myocardial infarction patients with an INR value of 2-3.

Conclusion: As a result, we believe that patients who is under oral anticoagulant therapy, always carrying a risk of ischemic diseases and in this patient group risk factors are different from well known risk factors, so there will be a need for more work on this issue.

\section{ÖZET}

Amaç: İskemik hastaliklarda tercih edilen tedavi yöntemleri ile birçok komplikasyon gelișebileceği gibi, tedavi altındaki hastalarda tekrar bir iskemik hastalıkta görülebilmektedir. Bu çalışmamızda herhangi bir nedenden dolayı oral antikoagülan kullanan ve INR değeri 2-3 aralı̆̆ında olan hastalarda gelişsen iskemik hastalıkların nedenlerini, risk faktörlerini ve demografik özelliklerini incelemeyi amaçladık.

Materyal ve Metod: 01.01.2014-31.12.2015 tarihleri arasinda acil servise bașvuran miyokard enfarktüsü, iskemik serebro vasküler hastalık ve pulmoner emboli tanısı alan hastaların dosyaları geriye dönük olarak incelendi. INR değeri 2-3 aralı̆ğnda olan ve oral antikoagülan kullanan hastaların verileri hastane otomasyon sisteminden bulundu. Elde edilen veriler SPSS 17 Istatistiki analiz programı eşliğinde değerlendirildi.

Bulgular: Çalışmaya alınan 452 pulmoner emboli hastasinın 24'ünde, 1442 iskemik serebrovasküler hastasının 24'ünde, ve 1263 myokard enfarktüsü hastasinın 55 'inde INR değeri 2-3 aralığında tespit edildi. 55 myokard enfarktüsü hastasindan 6 kişi, 24 pulmoner emboli hastasından 3 kişi ve 24 serebrovasküler hastasından 3 kişi özgeçmişinde ayn hastalğa yakalanmıştır. Pulmoner mmboli tanısı alan hastalarda yüksek Wells skorlarl ve büyük damar embolileri INR seviyesi tedavi aralı̆gnda olan grupta daha az görülmüşür. İskemik inme tanısı alan hastalarda atriyal fibrilasyon, INR seviyesi tedavi aralı̆gında olan grupta anlaml olarak daha fazla bulunmuştur. INR değeri 2-3 aralığında olan myokard enfarktüsü hastalarında konjestif kalp yetmezliği, atrial fibrilasyon ve pulmoner emboli yüksek bir risk faktörleri olarak saptandl.

Sonuç: Sonuç olarak oral antikoagülan tedavi altında olan hastalarında her zaman iskemik bir hastallk geçirme yönünden risk altında olduğu ve bilinen risk faktörleri ile bu hasta grubu arasında farklar olabileceği bu konuda daha fazla çalışmaya ihtiyaç olduğu kanaatindeyiz.
\end{abstract}

Key Words:

Anticoagulants,

Ischemia

Pulmonary embolism, Stroke,

Myocardial infarction.
Anahtar Kelimeler:
Antikoagülanlar,
İskemi
Pulmoner emboli,
Inme,
Miyokard enfarktüs.

\section{INTRODUCTION}

Ischemic diseases (myocardial infarction, ischemic cerebro vascular disease, pulmonary embolism) are diseases that can be seen in all periods of life, have high mortality and morbidity, are relatively easy to diagnose but have high cost and are modifiable and non-modifiable risk factors for protection (1). Although the risk factors that can be prevented, patients with ischemic disease are likely to have the same ischemic disease again or have another 


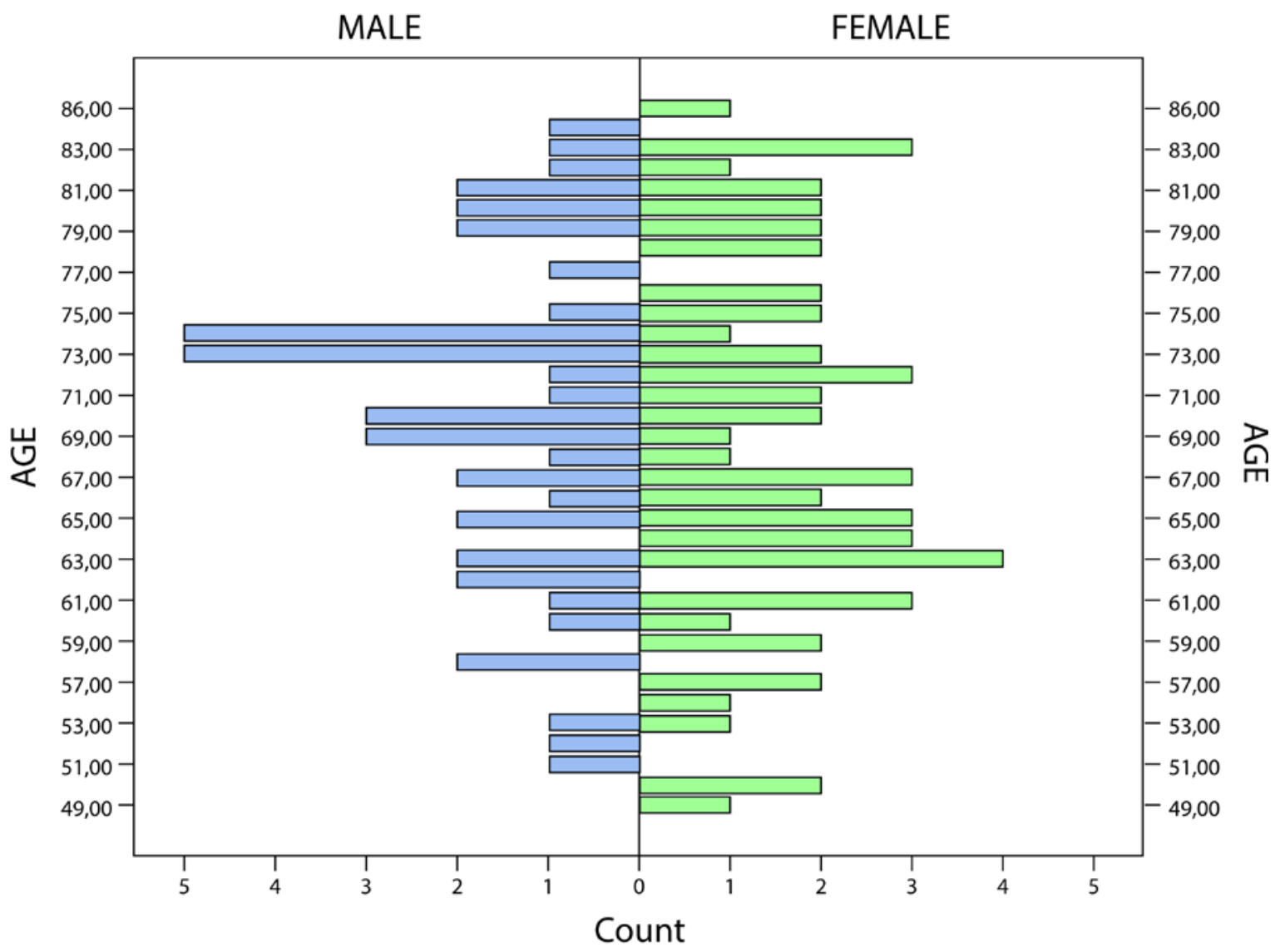

Figure 1: Age distribution of patients with repeated ischemic diseases by gender

ischemic disease. The main reason of this is arterial or venous coagulation. Although patients use oral anicoagulant agents, ischemic diseases repeat $(2,3)$ In this study, we aimed that to investigate dermographic characteristics, risk factors, and causes for patients, who has ischemic disease while under treatment and emphasize that even the

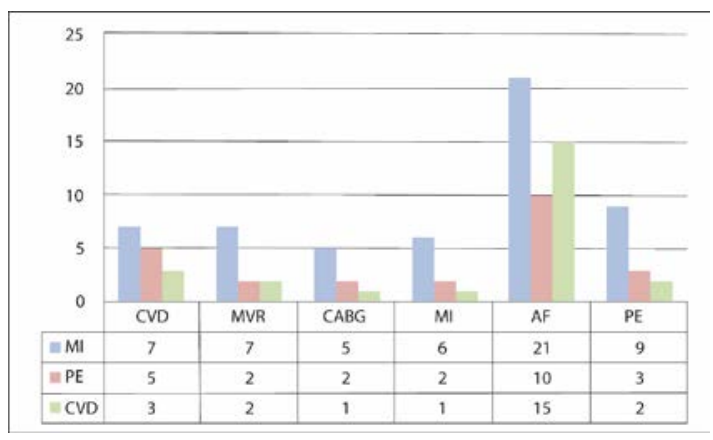

Figure 2: Reason for drug use in patients who are using oral anticoagulant drugs at an effective level MVR: Mitral valve replacement, CABG: coronary artery bypass graft, AF: atrial fibrillation.

We retrospectively investigated the files of the patients with myocardial infarction (MI) or effective use of anticoagulation cannot prevent ischemic diseases.

\section{MATERIAL AND METHODS}

This retrospective study was carried out in line with research regulations, including the approval of the Ethic Committee of our institute dated 22.03.2016 and numbered 27/25 and according to the principles of the "World Medical Associaotion Helsinki declaration"

ischemic cerebro vascular disease (CVD) or

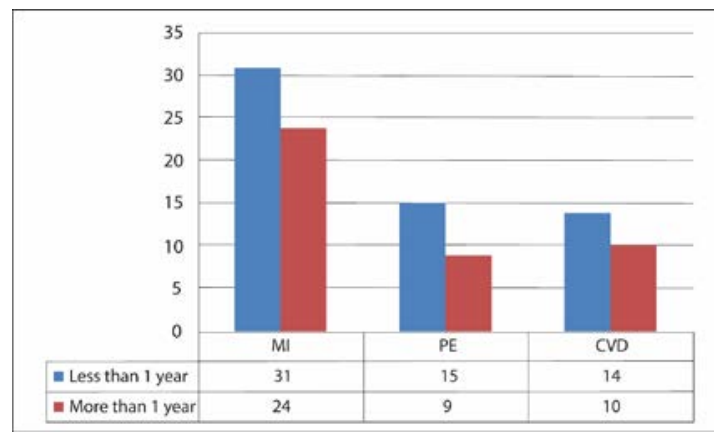

Figure 3: Patient Distribution by Duration of Oral Anticoagulant Drug Use 
pulmonary embolism (PE) children who admitted to our emergency department between January 2014 to January 2016. We included 103 patients who use oral anticoagulation drug effectively (INR: 2-3). Patients ages, genders, why do they use oral anticoagulation and how long they use oral anticoagulation, adjustment of oral anticoagulation longer or lesser then two months, and risk factors are recorded.
The statistical analyses is performed by SPSS 17.0 for Windows package program. The continuous variables are expressed as mean \pm sd for normally ditributed data and median (min-max) for data that are not normally distibuted; categorical variables expressd as n (\%).Pearson Chi-Square and Fisher's exact test test is used for categorical variables. $\mathrm{p} \leq$ 0.05 was regarded as significant with $95 \%$ confidence interval.

Table 1: Distribution of patients with pulmonary embolism by risk factors

\begin{tabular}{|c|c|c|c|}
\hline \multicolumn{4}{|c|}{ Patients with Pulmonary Embolism } \\
\hline & INR $<2$ n:428 & $\mathbf{2}<$ INR $<3$ n:24 & $\mathrm{P}^{*}$ \\
\hline Male gender & 186 & 9 & 0.57 \\
\hline Hypertension & 202 & 13 & 0.51 \\
\hline Atrial Fibrillation & 45 & 10 & $<0.01$ \\
\hline $\begin{array}{l}\text { Congestive } \\
\text { Failure }\end{array}$ & 97 & 8 & 0.23 \\
\hline Diabetes Mellitus & 118 & 9 & 0.29 \\
\hline $\begin{array}{l}\text { Ischemic stroke (large } \\
\text { artery) }\end{array}$ & 147 & 3 & 0.03 \\
\hline $\begin{array}{l}\text { Ischemic stroke (small } \\
\text { artery) }\end{array}$ & 78 & 5 & 0.75 \\
\hline WELLS (+) & 273 & 9 & 0.01 \\
\hline
\end{tabular}

Table 2: Distribution of patients with Ischemic stroke by risk factors

\begin{tabular}{|c|c|c|c|}
\hline \multicolumn{4}{|l|}{ Patients with Ischemic Stroke } \\
\hline & INR<2, n:1418 & $\mathbf{2}<$ INR $<3, \mathrm{n}: 24$ & $\mathrm{P} *$ \\
\hline Male Gender & 802 & 12 & 0.52 \\
\hline Hypertension & 933 & 15 & 0.74 \\
\hline Hyperlipidemia & 566 & 6 & 0.14 \\
\hline Ischemic Heart Disease & 559 & 11 & 0.52 \\
\hline Atrial Fibrillation & 546 & 17 & $<0.01$ \\
\hline Diabetes Mellitus & 453 & 8 & 0.88 \\
\hline Congestive Heart Failure & 307 & 9 & 0.06 \\
\hline Carotid Artery Stenosis & 172 & 4 & 0.33 \\
\hline Ischemic stroke (large artery) & 318 & 2 & 0.07 \\
\hline
\end{tabular}

Table 3: Distribution of patients with Myocardial Infarction by risk factors

\begin{tabular}{|c|c|c|c|}
\hline \multicolumn{4}{|c|}{ Patients With Myocardial Infarction } \\
\hline & INR<2, n:1208 & $\mathbf{2}<\mathbf{I N R}<3, \mathrm{n}: 55$ & $\mathrm{P}^{*}$ \\
\hline Male Gender & 881 & 25 & $<0.01$ \\
\hline Hypertension & 752 & 27 & 0.05 \\
\hline Hyperlipidemia & 602 & 14 & $<0.01$ \\
\hline Congestive Heart Failure & 429 & 32 & 0.001 \\
\hline Diabetes Mellitus & 315 & 19 & 0.16 \\
\hline Atrial Fibrillation & 253 & 26 & $<0.001$ \\
\hline Ischemic stroke & 197 & 8 & 0.73 \\
\hline Pulmonary embolism & 94 & 12 & $<0.01$ \\
\hline
\end{tabular}




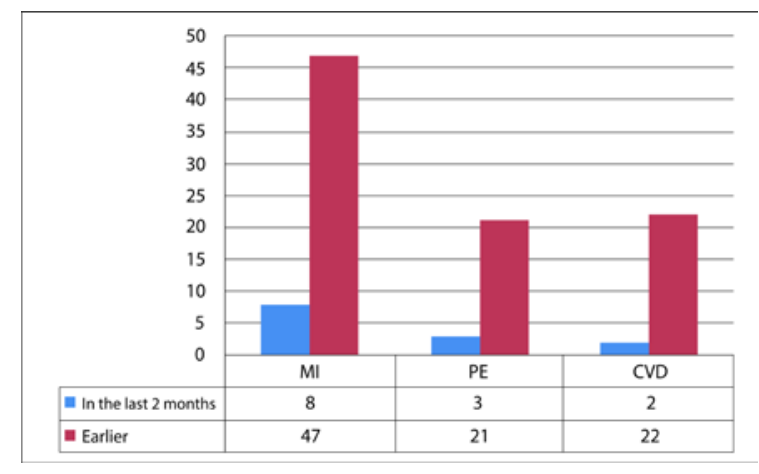

Figure 4: Patient Distribution by Time of Oral Anticoagulant Dose Change

\section{RESULTS}

The mean age of the patients was $67.4 \pm 4.9$ (Figure 1). The most frequent repeated ischemic disease was myocardial infarct $53.4 \%$ (55 patients), ischemic stroke 23.3\% (24 patients), pulmonary embolism 23.3\% (24 patients).

The reason for oral anticoagulant therapy was shown in figure 2 and the most frequent reason was atrial fibrillation.

30 of the MI patients were male, 25 were female, 15 of the PE patients were male, 9 were female, 12 of the ischemic stroke patients were male and 12 were female. Male and female distribution in ischemic stroke patients were equal while male gender dominance in MI and PE patients.

When we looked at the duration of oral anticoagulant drug treatment, it was determined that the number of initiation of treatment in all three groups within the last year was higher. 31 patients with MI, 15 patients with $\mathrm{PE}$ and 14 patients with ischemic stroke had been taking oral anticoagulants for less than a year (Figure 3).

Patients who took dose adjustment for oral anticoagulant drugs less than two months has been lesser risk for ischemic disease while they had been using oral anticoagulant (Figure 4).

Most of the patients with new ischemic events with INR level control in the last month remained low compared to patients who had been delayed follow-up for more than a month (Figure 5).

Similar rates are observed in all three ischemic diseases when the odds of re-developing the same disease. 6 people $(10.91 \%)$ out of 55 MI patients, 3 people (12.50\%) out of $24 \mathrm{PE}$ patients and 3 people (12.50\%) out of 24 ischemic stroke patients had the same disease.

It was observed that while there was no statistically significant difference between genders in terms of how long they had been taking the drug and the most recent dose adjustment, there was a significant difference in

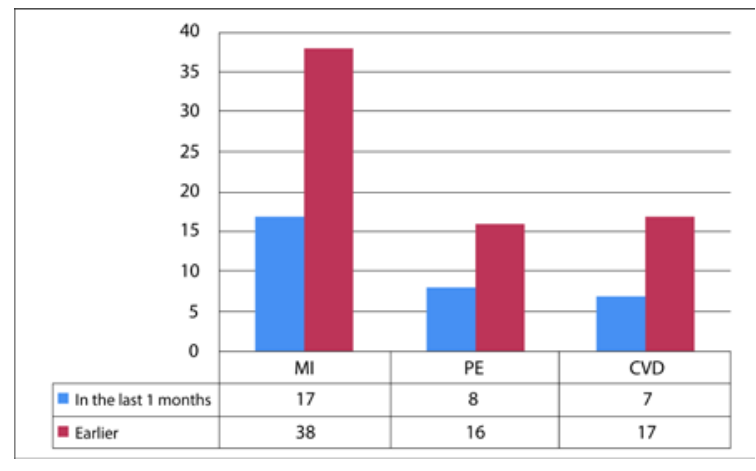

Figure 5: Patient distribution by last INR control time

INR follow-up and women did not follow-up longer than men in terms of INR follow-up.

When we compared patients diagnosed with pulmonary embolism according to risk factors (Table 1), We found that Wells criteria were more significant in the diagnosis in patients whose INR value was normally determined (INR $<2$ ). Wells scores of patients with INR levels in the treatment range were significantly lower than those of the other group $(p=0.01)$. In addition, patients diagnosed with atrial fibrillation were significantly more likely in the group whose INR level was within the treatment range $(p<0.001)$. Another important result was the rarity of large vascular embolisms in patients using oral anticoagulants $(\mathrm{p}=0.03)$.

In patients with ischemic stroke, atrial fibrillation was significantly higher in the group with an INR value of $<2(p=0.001)$. No significant difference was detected when looking at other risk factors (Table 2). when we look at large vascular embolism in ischemic stroke patients, it was observed that it was less common in patients using oral anticoagulants, but this difference was not statistically significant $(\mathrm{p}=0.07)$.

When MI patients were compared with risk factors, many differences were found between patients receiving oral anticoagulant therapy with INR values in the range of 2-3 and patients with INR values less than two. Male sex and hyperlipidemia were significantly higher risk factors in patients with normal INR values, while heart failure, atrial fibrillation and pulmonary embolism were statistically significantly higher risk factors in patients with INR values in the 2-3 range (Table 3).

\section{DISCUSSION}

Patients with ischemic disease are likely to have the same ischemic attack again or have another ischemic disease. The main source of this is arterial or venous thrombus or embolism. Incidence of recurrent ischemic diseases are respectively myocardial infarction, ischemic stroke and pulmonary embolism (4). In our study, MI (53.4\%) was found the most frequent disease 
in ischemic diseases in patients using oral anticoagulants at an effective level, consistent with litarature. PE (23.3\%) and stroke (23.3\%) rates were the same.

Although the risks of recurrent ischemic stroke are not very different from those of the first ischemic stroke, the most common risk is having a previous ischemic stroke. However, hypertension (75\%), hyperlipidemia (56\%) ischemic heart disease (37\%), atrial fibrillation (29\%), male gender (57\%), diabetes mellitus (24\%), smoking (13\%), obesity (11\%), mechanical heart valve (\%0.9) are the other risk factors (5). 51\% of patients with recurrent ischemic stroke have three or more of these risk factors. Recurrent ischemic stroke attacks generally recur one year after the previous attack. Compared to patients with recurrent ischemic stroke, $21 \%$ of the patients in the risk group who had ischemic stroke were treated with anticoagulant therapy (6). In our study, we found recurrent ischemic stroke in $12.5 \%$ of patients who had ischemic stroke despite using an effective dose of oral anticoagulant. These three patients had an average age of 67.2 years, all three patients had hypertension and two patients had atrial fibrillation. In the literature, repeated ischemic stroke patients with anticoagulants, atrial fibrillation was the most frequently risk factor, followed by patients with hypertension and hyperlipidemia, diabetes mellitus and ongoing smokers.

Risk factors in pulmonary embolism are not different from venous thrombosis risk factors, but the history of surgical intervention in the last 45-90 days increases the risk of thromboembolism by 6-22 times. Previous pulmonary embolism increases the risk by $10 \%$, previous myocardial infarction 5-35\%, congestive heart failure $9-21 \%$, chronic obstructive pulmonary disease $3.3-8.9 \%$ and cancer $4-28 \%$ (6). Apart from these, genetic studies should be done in recurrent venous thromboembolism. Deep vein thrombosis was detected in one third of antiphospholipid syndrome cases and $10 \%$ of antiphospholipid syndrome cases were pulmonary embolism (7). Similar to the literature, in patients with recurrent pulmonary embolism, although in the first attack female sex is more common, male sex is more likely in having a recurrent attack (8). In this study, we detected recurrent $\mathrm{PE}$ in $12.5 \%$ of $\mathrm{PE}$ patients using an effective dose of oral anticoagulant. When we look at the risk factors of these cases, the average age of all three women was 55.4 years and two patients had undergone operations within the last 4 months. In our study, the group with the highest risk was who had hypertension, followed by atrial fibrillation, diabetes mellitus, male sex, congestive heart failure and ischemic stroke.

The Wells score, which we used to predict pulmonary embolism, was more successful in predicting the disease in patients who had pulmonary embolism for the first time, while the sensitivity decreased in predicting the disease in patients who used oral anticoagulants. The main reason for PE is; chronic diseases (hypertension, congestive heart failure, diabetes mellitus, hyperlipidemia) may increase atherosclerosis in the pulmonary arteries, then embolism (8). In our study, Wells score was found lower in patients using oral anticoagulants at an effective dose. This may be because there is zero scores from no alternative diagnosis and newly detected DVT. Our patients had no history of trauma or surgery.

While atrial fibrillation is more of a cause of ischemic stroke, it also poses a risk of pulmonary embolism, as well as AF is a cause of oral anticoagulant use. Atrial fibrillation alone does not increase the frequency of pulmonary embolism. However, if there are signs of newly started dyspnea and a suspected pulmonary embolism, AF lowers that probability. But if chest pain is a symptom and pulmonary embolism is suspected, then AF increases the odds (9). In our study, AF rate was high in patients who had pulmonary embolism with an effective dose of oral anticoagulant treatment.

In this study, AF was the highest risk factor in patients with recurrent MI, respectively, having ischemic stroke, hyperlipidemia, hypertension, heart failure (Killip >1), having a new left branch block in ECG, and reperfusion were listed. Having male sex is higher than female sex as a risk in first-time or recurrent MI (10). If atrial fibrillation is chronic, there is no risk in recurrent MI. However, the AF detected at hospital admission or the AF detected during hospitalization were found to be significant in recurrent MI(10). Our study coincides with this information. In our study, we determined $10.9 \%$ of 55 MI patient, had recurrent MI. The average age of six patients was 57.3 years and five patients were male and one patient female. Three patients had a combination of hypertension and diabetes mellitus risk factors, two patients had a combination of smoking and diabetes mellitus risk factors. The other patient had only smoking risk factor.

In our study, the highest risk group was patients with heart failure; afterwards respectively, hypertension, $\mathrm{AF}$, male gender, diabetes mellitus, hyperlipidemia, patient had PE and patient had ischemic stroke. It was determined that as a risk factor AF was present after patients with hypertension or heart failure.

Although effective level of oral anticoagulation was used, AF was found to be the most serious risk factor in all three ischemic diseases (ischemic stroke, pulmonary embolism, myocardial infarction). Atrial fibrillation does not a primary risk factor both in PE and in MI. However, in patients under oral anticoagulant therapy, the newly identified atrial fibrillation is a higher risk factor.

Male sex has high risk in both the first ischemic event and recurrent ischemic events in all three diseases. Although the risk is higher in women over 65 who have atrial fibrillation than men (11). In our research, male sex had higher risk in all areas. 


\section{Dibek et al.}

In conclusion, The main problem in all ischemic diseases are modifiable risk factors such as endothelial damage, hypertension leading to intimal thickening, hyperlipidemia, diabetes mellitus, smoking and obesity. With the effective use of oral anticoagulant drugs, ratio of these risk factors can change.

Conflicts of Interest

\section{REFERENCES}

1- Tsai AW, Cushman M, Rosamond WD, Heckbert SR, Polak JF, Folsom AR. Cardiovascular risk factors and venous thromboembolism incidence: the longitudinal investigation of thromboembolism etiology. Arch Intern Med. 2002;162:1182-9.

2- $\quad$ Riedel M. Venous Tromboembolic Disease, Acute Pulmonary Embolism: Pathophysiology, Clinical Presentation, And Diagnosis. Heart. 2001;85:229-240.

3- $\quad$ Kroegel C, Reissig A. Principle Mechanisms Underlying Venous Thromboembolism Epidemiology, Risk Factors. Respiration. 2003;70:730.

4- $\quad$ Ansell J, Hirsh J, Hylek E, Jacobson A, Crowther M, Palareti G. Pharmacology and Management of the Vitamin K Antagonists: American College of Chest Physicians Evidence-Based Clinical Practice Guidelines (8th Edition) Chest. 2008;133(6 Suppl):160S-198S.

5- $\quad$ Leoo T, Lindgren A, Petersson J, Arbin Mv. Risk Factors and Treatment at Recurrent Stroke Onset: Results from the Recurrent Stroke Quality and Epidemiology (RESQUE) Study. Cerebrovasc Dis. 2008;25:254-260.

6- $\quad$ Tapson VF. Acute pulmonary embolism. N Engl J Med. 2008;358:1037-52.

7- British Thoracic Society Standards of Care Committee Pulmonary Embolism Guideline Development Group. British Thoracic Society guidelines for the management of suspected acute pulmonary embolism. Thorax. 2003;58:470-84.

8- Prandoni P, Noventa F, Ghirarduzzi A, Pengo V, Bernardi E, Pesavento R, et al. The risk of recurrent venous thromboembolism after discontinuing anticoagulation in patients with acute proximal deep vein thrombosis or pulmonary embolism. A prospective cohort study in 1,626 patients. Haematologica. 2007;92:199-205.

9- Gex G, Gerstel E, Righini M, LE Gal G, Aujesky D, Roy PM, et al. Is atriyal fibrillation associated with pulmonary embolism? J Thromb Haemost. 2012;10:347-51.

10- Saito D, Shiraki T, Oka T, Kajiyama A, Takamura T. Risk Factors Indicating Recurrent Myocardial Infarction After Recovery From Acute Myocardial Infarction. Circ J. 2002;66:877-80.

11- Feigin VL, Carlene MML, Bennett DA, Anderson CS. Stroke epidemiology: a review of population-based studies of incidence, prevalence and case-fatality in the late 20th century. Lancet Neurol. 2003;2:43-53. 